for 1931. While primarily intended for medical, research and administrative officers, the information given should also prove useful for those visiting the Colonies and Dependencies for pleasure, or those intending to reside there. The vital statistics included should also prove of value to insurance offices and business houses.

\section{Polar Year Book}

THE "Polar Arboken" for 1933 is the first annual publication of the Norwegian Polar Club. It is a well-illustrated little volume containing a number of papers by well-known polar travellers on various aspects of Norwegian activity in north and south polar regions. Most of the articles are of general rather than scientific value, but they include much useful information about whaling, coal mining in Spitsbergen and hunting in various parts of the arctic.

\section{Announcements}

THE Organising Committee of the Sixth International Botanical Congress has decided to change the date of meeting of the Congress. The Congress will meet at Amsterdam on September 2-7, 1935. The secretary is Dr. M. J. Sirks, Wageningen, Holland.

LEverHULme research fellowships have been awarded to Miss E. M. Denby, organising secretary of the Kensington Housing Trust, Ltd., to study slum clearance and rebuilding at home and abroad; and to Miss D. A. E. Garrod, for excavation of palæolithic cave sites on Mount Carmel, Palestine.

Tнe Secretary of State for the Colonies has recently made the following Colonial agricultural appointments : Mr. E. J. Gregory to be manager, St. Augustine Experimental Station, Trinidad; Mr. A. Thompson, assistant mycologist, to be mycologist, Agricultural Department, Malaya.

The Williams prize of the Iron and Steel Institute has this year been awarded jointly to Mr. D. F. Marshall, of Sheffield, for his paper on "The External Heat Loss of a Blast-Furnace", which was presented at the last annual meeting of the Institute in London, and to Mr. A. Robinson, of Scunthorpe, for his paper on "Some Factors Leading to Greater Production from a Steel Furnace", which was presented at the autumn meeting of the Institute held in Sheffield in September last.

AT the annual general meeting of the Cambridge Philosophical Society, the following officers were elected :-President, Prof. J. Barcroft ; Vice-Presidents, Dr. F. H. A. Marshall, Dr. F. W. Aston, Prof. E. K. Rideal ; Treasurer, Mr. F. A. Potts ; Secretaries, Mr. F. P. White, Dr. J. D. Cockeroft, Dr. H. Hamshaw Thomas; New members of Council, Mr. F. T. Brooks, Prof. J. E. Lennard-Jones, Mr. H. L. H. H. Green, Dr. O. M. B. Bulman, Mr. P. I. Dee.

THE following officers of the University of Durham Philosophical Society have recently been elected for the Session 1933-34: President, Prof. R. A.
Sampson; Hon. General Secretary, Mr. W. M. Madgin; Hon. Treasurer, Mr. J. W. Bullerwell; Editor, Prof. G. W. Todd; Assistant Editor, Mr. J. F. Wood; Hon. Librarian, Dr. F. Bradshaw; Assistant Librarian, Mr. F. Patterson.

THE Institute of Metals now issues a monthly set of abstracts of the world's metallurgical literature, and follows this up by re-issuing these abstracts in volume form, with index, at the end of the year. In accordance with a scheme that has recently been adopted by the Council, the issue of separate 'preprints' of papers to be read at the two half-yearly meetings just before each meeting will cease. Instead, the advance copies will appear, two or three at a time, in the Institute's monthly Journal along with the metallurgical abstracts. As in the case of the latter, the papers will be re-issued in volume form later for permanent retention.

The Food Group of the Socioty of Chemical Industry will hold a symposium on "Bread and Milk" in the Hall of the British Medical Association, Tavistock Square, London, W.C.1, on Thursday and Friday, November 23-24. The symposium is to be divided into three sessions under the chairmanship of Prof. W. W. Jameson, Sir John Russell, and Prof. H. E. Armstrong, respectively. Papers will be read by the following: Prof. H. D. Kay (Reading), Prof. A. J. Kluyver (Delft), Prof. A. D. Orla-Jensen (Copenhagen), Dr. E. T. Minett and E. J. Pullinger (London), Prof. J. R. Katz (Amsterdam), Holger Jorgensen, Prof. Max Samec (Czechoslovakia), Dr. H. G. Bungenberg de Jong (Utrecht), C. W. Brabender (Duisberg), Prof. J. C. Drummond (London), Prof. G. S. Wilson and M. P. Cowell (London), Dr. J. Vargas Eyre (Epsom), Dr. D. W. Kent-Janes (Dover) and W. Jago (Hove). Applications for invitations and further information should be made to the Secretary, Food Symposium, Society of Chemical Industry, 46, Finsbury Square, London, E.C.2.

APPLICATIONs are invited for the following appointments, on or before the dates mentioned :-A lecturer in chemistry in Rhodes University College, Grahamstown-The Secretary, Office of the High Commissioner of South Africa, Trafalgar Square, London, W.C.2 (Nov. 30). A head of the School of Pharmacy in the Robert Gordon's Technical College, Aberdeen-The Secretary (Nov. 30). An engineer to the Essex Rivers Catchment Board-The Clerk of the Board, Dorset House, Duke Street, Essex (Dec. 1). A student probationer (zoologist or physiologist) at the Marine Biological Laboratory, Plymouth (Dec. 3I). An assistant curator at the Raffles Museum, Singapore, Straits SettlementsDirector of Recruitment (Colonial Service), Colonial Office, 2, Richmond Terrace, Whitehall, London, S.W.1 (Jan. 31). A director of water examination to the Metropolitan Water Board-The Clerk of the Board, Offices of the Board, 173, Rosebery Avenue, London, E.C.1 (Feb. 10). A chemist to the Sudan Government, Khartoum-The Controller, Sudan Government London Office, Wellington House, Buckingham Gate, London, S.W.1. 